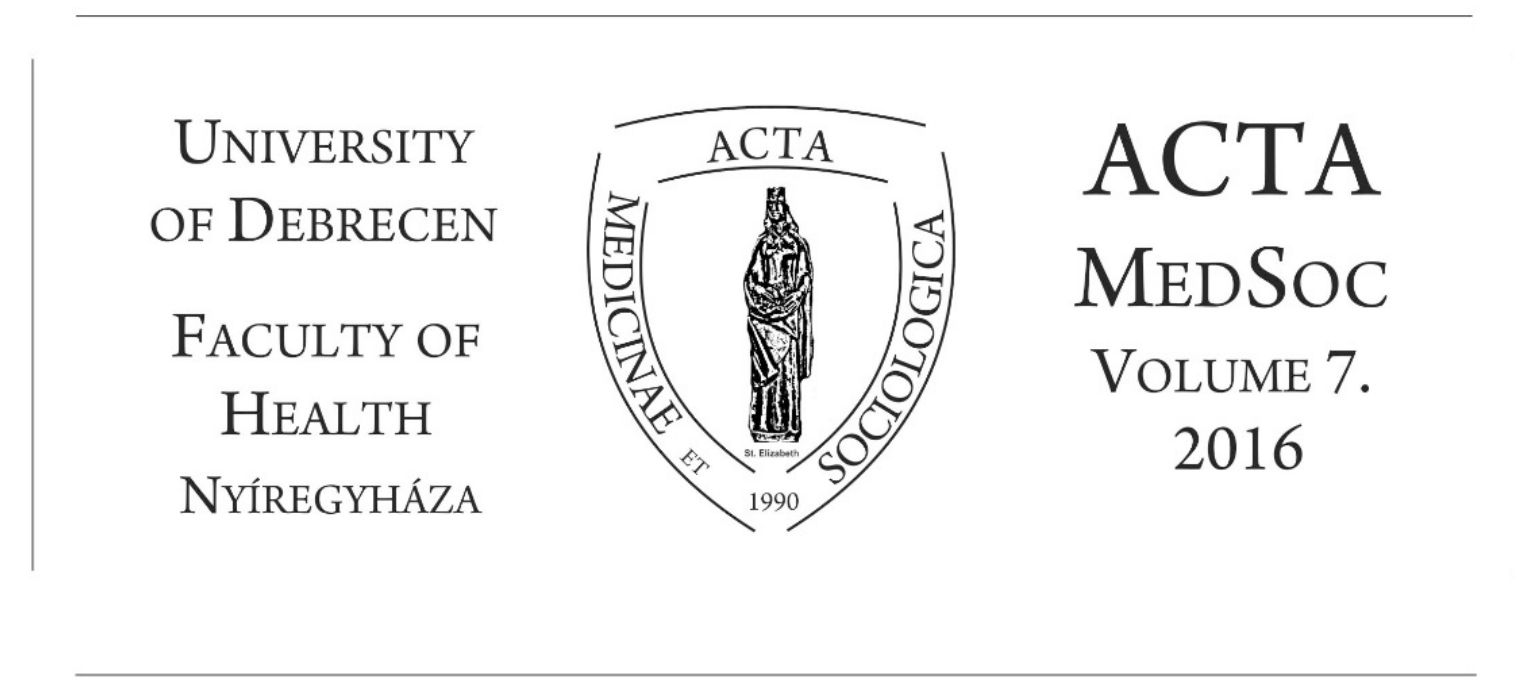

\title{
A Jó, a Rossz és a Csúf, avagy a nyíregyházi fiatalok élethelyzete napjainkban
}

\section{The Good, the Bad and the Ugly - or the living situation of young people in Nyíregyháza today}

Bár hazánkban viszonylag sok kutatás foglalkozik a fiatalok életminőségével, gazdasági-társadalmi helyzetével, egészségmagatartásával (ilyen pl. a Magyar Ifjúság kutatássorozat, vagy a serdülőkorú fiatalok egészségét és életmódját feltáró nemzetközi összehasonlító vizsgálat, a HBSC), viszonylag ritka, hogy mindezeket lokális szinten is részletesen feltárják a kutatók.

Erre vállalkozott 2015-ben a HumánNet Alapítvány és a Debreceni Egyetem Egészségügyi Karának Szociális és Társadalomtudományi Intézete, azzal a céllal, hogy átfogó képet kapjon a városban élő 15-18, illetve 19-29 éves korosztályok élethelyzetéről. A kutatás dimenziói mindkét korosztály esetében követték a Magyarország ifjúsága vizsgálatsorozat dimenzióit, így az adatok regionális és országos összehasonlíthatósága is biztosított volt. Sor került (többek között) a fiatalok tanulási motivációinak feltárására, szabadidős tevékenységeinek a vizsgálatára, a médiafogyasztás elemzésére, a közéleti aktivitás, vagy éppen a lakhatás és lakáskörülmények feltérképezésére. A tematikusan igen színes kutatás 
eredményeit tartalmazó kötetet tarthatja kezében az olvasó. A könyv lehetőséget kínál arra, hogy a tanulmányok átolvasása után átfogó képet alkothassunk napjaink fiataljainak életéről, de azt is lehetővé teszi, hogy az olvasó elmélyülhessen egy-egy témakörben, részletes információkkal gyarapodhasson az adott, konkrét és alaposan feltárt terület jellemzőiröl.

...A Jó...

A kutatás adatai egy rendkívül gyermek centrikus és házasságpárti, helyi fiatal társadalom jelenlétéről árulkodnak, ahogyan azt R. Fedor Anita elemzése részletesen is bemutatja. A fiatalok nemcsak házasságpártiak, többségük a hagyományosnak mondható kétgyermekes családmodellt preferálja, igen kevesen vannak olyanok (a válaszadók mindössze 5 százaléka), akik nem szeretnének gyermeket vállalni. Meglepő eredménye a vizsgálatnak, hogy az országos kutatások eredményeivel szemben Nyíregyházán a fiatalabb, azaz a 15-18 éves korosztály tagjai sokkal határozottabban állnak ki a házasságkötés mellett, mint idősebb társaik. A vizsgálat tanulsága, ahogyan arra a szerző is utal: „A válaszadásból levonható konklúzió egy igen eröteljes tradicionális attitüdröl árulkodik, valamint arról, hogy a házasság intézménye a mai napig egy erős, biztonságot nyújtó köteléket jelent az érintettek többségének, mely nem csak az érzelmileg egymáshoz kötödö fiataloknak, de a gyerekek fejlödése szempontjából is a legjobb párkapcsolati formula".

Ezeket a véleményeket magyarázza Takács Péter és Huszti Éva közös tanulmánya, mivel megállapításuk szerint a teljes minta $63 \%$-a él vér szerinti szüleivel és testvérekkel vagy azok nélkül. A megkérdezett fiatalok majdnem fele (48\%) él klasszikus, nukleáris családban: anya, apa, testvér. A szerzőpáros elemzése természetesen nemcsak a családi körülményekre koncentrál, részletesen vizsgálja a szülöi hátteret, illetve az objektív anyagi helyzetet és annak szubjektív megítélését is. Több kutatás eredményeivel összehasonlítva ez utóbbi kedvezőbb képet mutat a nyíregyházi fiatalok esetében. „Arra a kérdésre, amelyben arra voltunk kíváncsiak, hogy a megkérdezettek összességében hogy látják, hogyan érzékelik anyagi helyzetüket, a fiatalok 28\%-a mondta azt, hogy úgy érzik, anyagilag gondok nélkül élnek. 45\%-uk mondta azt, hogy beosztással jól kijönnek, 16\%-uk úgy értékelte helyzetüket, hogy éppen kijönnek a jövedelmükböl, 8\%-uk pedig arról számolt be, hogy érzésük szerint hónapról-hónapra anyagi gondjaik vannak. A megkérdezett fiatalok 3,5\%-a mondta azt, hogy nélkülözések között élnek”. A megkérdezett fiatalok 15\%-a él olyan háztartásban, ahol a kérdezés előtti 12 hónapban havi rendszerességgel fordult elő az, hogy hónap végére elfogyott a pénzük. Ez az arány a 2012-es országos kutatás adatai szerint $25 \%$-os, és még ettől is rosszabb képet mutat a Szabolcs-Szatmár-Bereg megyére vonatkozó adat, miszerint a megkérdezettek 46\%-a mondta azt, hogy havi szinten szembesülnek anyagi gondokkal. Az összevetésben kedvezőbb életkörülmények ismét tükrözik 
Nyíregyháza „sziget” jellegét, amely vélhetően igaz lehet a többi hazai megyeszékhelyre és nagyobb városra is.

A nyíregyházi fiatalok döntő többsége nyitott a tanulásra és a továbbtanulásra, bizakodóak és motiváltak, munkaerő-piaci karrierjük és lehetőségeik terén optimisták. Igaz, mérhetőek bizonyos különbségek az egyes korcsoportok között, hiszen ahogyan ezt Fónai Mihály és Szigeti Fruzsina közös tanulmányukban igen plasztikusan be is mutatják, a 15-18 évesek számára a szakma, az érettségi és a felsőfokú végzettség megszerzése még egyaránt potenciális lehetőség. Csaknem kilenctizedük tervezi azt, hogy továbbtanul, szemben a 19-29 évesekkel (akik között persze többen szereztek már valamilyen szakképesítést), akiknek csak a fele tervez továbbtanulást, ami elsősorban szakmai képzést vagy egyetemi mesterdiplomát jelent.

Ezeket az eredményeket erősíti meg Kállai Barbara, Lengyelné Pogácsás Mária és Nyírcsák János elemzése, akik nemcsak a fiatalok oktatási rendszerben betöltött helyét vizsgálták, hanem ezzel összefüggésben a fiatalok mobilitási törekvéseit is, ideértve a külföldi tanulásra, a külföldi munkavállalásra vonatkozó aspirációkat. Következtetésük, hogy a legfiatalabb korosztály tagjai (legalábbis a szándékok szerint) mobilabbak, mint idősebb társaik, hiszen ,a 19-29 éves korosztály esetében nagyobb arányban vannak azok, akik nem hagynák el az országot, és kevesebben vannak közöttük azok is, akik véglegesen is hajlandóak lennének másik országot választani lakóhelyül”. A tanulmány kiválóan érzékelteti azt az örök dilemmát, amely a motiváló tényezők, azaz a jobb megélhetés, a karrier és a visszatartó erők, vagyis a család, a barátok elhagyása és a hazájukhoz való ragaszkodás között feszül.

Más szempontból ugyan, hiszen az elemzés elsősorban a lakhatás körülményeire koncentrál, de Szoboszlai Katalin írása is elemzi a nyíregyházi fiatalok mobilitási szándékait. Az egyes korcsoportok közötti különbségek itt is megjelennek, a 18 év alattiak közel negyven százaléka határozottan költözéspárti, igaz, mindössze 5 százalék menne külföldre és csupán 3 százalék valamilyen más településre, ami azt jelenti, hogy szívesen maradnának a városban, de önálló, a szülőktől már különálló háztartásban. Velük szemben az idősebbeknek már csak 31 százaléka költözéspárti, a korosztály 25 százaléka a jövőben is Nyíregyházán szeretne élni. A tanulmány arra is rámutat, hogy a fiatalok döntő többsége elégedett jelenlegi lakhatási körülményeivel. A tanulmány nagy erénye, hogy számos, a várostervezés és a fiatalok megtartását szolgáló javaslatot is tartalmaz.

\section{...a Rossz és a Csúf...}

Különösen aggasztó információkkal szolgál Hüse Lajos írása, aki a nyíregyházi fiatalokra jellemző rizikómagatartást vizsgálta. Bár a drogfogyasztás terén nincs kimutatható érintettsége a vizsgált korosztálynak, az alkoholfogyasztás területén a 
nyíregyházi fiatalok az országos átlagnál veszélyeztetettebbek. A fiatalabb korosztály az ivás gyakorisága szempontjából, a fiatal felnőtt korosztály az alkoholfogyasztók aránya szempontjából mutat átlag fölötti eredményeket. A dohányzás terén is fokozottabb kockázati viselkedés jellemzi a nyíregyházi fiatalokat az országos átlaghoz képest. A tanulmány kitér a fiatalok érzelmi jólétének, stressz- és szorongásos helyzeteiknek a bemutatására is. Ezek azért is lényeges kutatási kérdések, mert a szerző elemzése szerint az öngyilkossági statisztikák is átlag feletti rossz eredményeket mutatnak a helyi fiatalság körében, közöttük pedig a lányok/nők körében különösen, mind az öngyilkosság gondolata, mind a megkísérelt öngyilkosságok terén. A pszichoszociális rizikófaktorokat vizsgálva beazonosíthatóvá vált egy magas rizikójú élethelyzetben lévő csoport is. A tanulmány erénye, hogy a szerző nem elégszik meg a helyzet elemzésével, az írás számos, megfontolásra érdemes javaslatot is tartalmaz.

Bár direkt összefüggés valószínűleg nem mutatható ki, a kapott eredmények hátterében „ott sejtjük” a fiatalok szabadidős preferenciáit is. Bár Kovács Klára tanulmányában azt is kiemeli, hogy a preferenciák nem mutatnak eltérést az országos jellemzőktől, mégis ,a nyíregyházi fiatalokat is elsősorban az otthoni, passzív, rekreativ, digitális közegben zajló szabadidö-eltöltés jellemzi. Amennyiben kimozdulnak otthonról, szabadidejüket leginkább barátaikkal töltik. A magaskultúra-fogyasztás szinte egyáltalán nem jellemzi a fiatalokat, de ez nemcsak korosztályi sajátosság, hanem sokkal inkább szocio-kulturális”. A nyíregyházi fiatalok szabadidejének jelentős része passzívan, otthoni környezetben, leginkább on-line környezetben telik, de a semmittevés is meghatározó, ráadásul minél alacsonyabb a szülök iskolai végzettsége, annál inkább.

Ezt az eredményt támasztja alá a kötet két másik tanulmánya is. Huszti Éva és Takács Péter a fiatalok médiahasználatát elemezve lényeges különbségeket talált az országos és a helyi jellemzők között. Az természetesen ma már nem jelent meglepetést, hogy a fiatalok szinte mindenre számítógépet és mobilkommunikációs eszközöket használnak, az eltérés ezek használatában jellemző. Ahogyan arra a szerzőpáros is utal: „a nyíregyházi fiatalok mind hétköznapokon, mind hétvégén idejük jelentős részét internetezésre szánják. Ez mind a 15-18 évesekre, mind a 1929 évesekre egyaránt jellemzö, és ez nem mutat eltérést az országos adatokhoz képest sem. Az internetezéssel töltött átlagos idö azonban magasabb a nyíregyházi mérésben, azaz a vizsgált fiatalok több idöt szánnak erre a tevékenységre, mint az országos átlag. Ami az internetes kommunikációt illeti, jelentös eltérés mutatható ki: az azonnali üzenetküldővel történö csetelés gyakorisága, az internetes telefonálás gyakorisága, a fórumokban, blogban való hozzászólás gyakoriságát tekintve is a nyirregyházi fiatalok nagyobb arányban végeznek ilyen tevékenységet gyakran, mint általában a fiatalok és alacsonyabb azok aránya körükben, akik soha nem végeztek még ilyen jellegü tevékenységet. A nyíregyházi fiatalok körében az országosnál 
magasabb jelenléti arány mérhetö az internetes közösségi oldalakon. A nyíregyházi fiatalok leggyakoribb napi tevékenysége a közösségi oldalon a saját magáról való hír, információ megosztása, illetve a hasonló jellegü információk kommentálása”.

A túlzott média és internethasználatra ma már számos hazai és nemzetközi vizsgálat felhívja a figyelmet, a kapott adatok tükrében ez a rizikófaktor a nyíregyházi fiatalokra is jellemző, különösen annak fényében, hogy körükben az információforrások egyik legpreferáltabb eszköze az Internet. Ezzel is eltérnek az országos átlagtól, hiszen ott a barátok, a család fontossága meghaladja az internetét.

Az internetgalaxis gyermekei abban is nagymértékben különböznek a korábbiaktól, hogy ez egy digitális generáció, beleszülettek a digitalizált világba, így minden digitális eszközt természetesnek vesznek, az emberek mindennapjainak nemcsak kiegészítéseként, hanem szerves részeként kezelik azokat. A mai fiatalok virtuális közösségekben élnek, a világhálón töltik szabadidejük nagy részét, és kapcsolataikat is az internetes közösségi oldalakon építik ki, félő azonban, hogy a virtuális térben nem tanulják meg a konfliktusokat megfelelően kezelni. Hazai kutatási eredmények szerint a magyar fiatalok egynegyede érzi úgy, hogy nem tud beilleszkedni a szük környezetébe, és sokkal könnyebben talál barátokra a virtuális térben.

Mindezeket Patyán László és Huszti Éva tanulmánya is alátámasztja, hiszen a nyíregyházi fiatalok alapvetően kevés társadalmi szerveződésnek tagjai, és társadalmi aktivitásuk az iskolarendszer elhagyásával még inkább csökken. Az összminta 68,5\%-a nem tagja semmilyen szervezetnek. Valamilyen tagság így csupán harmadukra jellemzö, ami alacsonyabb az egyébként is nagyon alacsony országos eredményekhez viszonyítva is (40\%). A szerzőpáros ráadásul arra is rámutat, hogy a fiatalok egy része kifejezetten elégedetlen emberi és társas kapcsolataival. A tanulmányban felszínre kerülnek a városi devianciákkal kapcsolatos problémák is, sőt, a válaszokból sajnálatos módon önálló kategóriát lehetett képezni az elöítéletekre vonatkozóan is (elsősorban, a hajléktalanok, cigányok, idősek kapcsán elhangzott kijelentések alapján). Ugyancsak említésre kerülnek az urbanizációs problémák, a szolgáltatások hiányosságai, a munkalehetőségek és boldogulás hiánya. Ugyanakkor bizakodásra adhat okot, hogy a 15-18 éves korosztály sokkal érzékenyebb a társadalmi problémák iránt, mint a 1929 éves csoport.

\section{...és természetesen a Szép...}

Bár a címben említett (a fiatal olvasók számára egy teljesen beláthatatlan múltban, 1966-ban, egy messzi-messzi galaxisban bemutatott, sokak által azonban a legwesternebb westernnek tartott film) szereplö felsorolás nem tartalmaz Szépet, a kötet kiváló (ha tetszik: szép) tanulmányai nemcsak negatív információkat tartalmaznak. Azon kívül, hogy a fiatal persze mindig szép, kirajzolódik egy, a 
világra és egyben a városra is nyitott, tanulni vágyó, gyermek centrikus, s még a problémák iránt is érzékeny ifjúság profilképe is. A filmben az egyik főhős (mára más szinte szállóigévé vált) mondása szerint: Kétféle ember létezik a világon, barátom: vannak, akiknek meg van töltve a fegyverük, és vannak, akik ásnak. Te ásol.

Szurkoljunk a mai fiataloknak, hogy töltött fegyverekkel induljanak a jövő felé, ne ők legyenek az ásók. A kutatás eredményei alapján erre minden esélyük adott.

Fábián Gergely 